\title{
Challenging Digital Capitalism: SACOM's Campaigns against Apple and Foxconn as
}

Monopoly Capital

PUN Ngai, Professor, Department of Sociology, The University of Hong Kong

Email: npun@hku.hk, Correspondent Author

Tommy TSE, Assistant Professor, Department of Sociology, The University of Hong Kong Email: tommyt@hku.hk

Kenneth NG, PhD Candidate, Department of Government and Public Administration, The Chinese University of Hong Kong

Email: ngtszfung@gmail.com

Acknowledgement:

We are grateful to Foxconn workers, student interns and SACOM activists especially Ken Yau, Sophia So, Sophie Chan and Lin Lin for the support of this action research. We are also thankful for the two reviewers who provided valuable and detailed comments for the writing of this article. The work described in this paper is partially supported by the CRF Group Research, "Learning to Labor: Social Media and Migrant Labor Protection in Mainland China” (C5010-15G), Research Grants Council of the Hong Kong Special Administrative Region.

Word count: 7950 


\begin{abstract}
“Utopia or dystopia — to where will the ‘digital revolution' lead human society?” is a question that remains unanswered. Negotiating between two opposing standpoints, this article, looking at a form of trans-border activism originally driven by suicides and protests of Foxconn workers who produce iPhones, iPads and many other i-gadgets for the world's consumers, is an attempt to explore a politics of online/offline resistance against anti-digital capitalism. Based in Hong Kong (HK), SACOM is a leftist student group which works to support Chinese workers in campaigning against corporate power and generating trans-border networks through media exposure, international activism, and localized organization. Combining online and offline activism, SACOM strives to extend the reach of their workerconsumer campaign to the worldwide audience by transgressing the Chinese state's dominance of capital and political control. The most intriguing question to us is could this proactive activism be possible and, if so, how could it act at the grid of China's transformation and incorporation into global capitalism?
\end{abstract}

\title{
Keywords:
}

Apple and Foxconn; digital capitalism, labor, trans-border activism. 


\section{Introduction}

“Utopia or dystopia— - to where will the ‘digital revolution’ lead human society?” is a question that remains unanswered. Yet this is not an issue of postmodern experimentalism as if the society could morph into a studio, inviting individuals to act out their experimental performance. In this “digital revolution,” human imagination, social power, the nation-state, and transnational capital all contribute to the formation and deformation of our everyday lives (Greenfield, 2017). After all, utopia or dystopia is a matter of social battles, grounded in the very solid, materialized base fighting for social conditioning, the constitution of meaning, and the positioning of speaking power. If we say that the medium of this battle looks like "all that solid melts into air” (Berman, 1983), the battle per se is as solid as a rock, involving class conflicts and class powers in the contemporary society.

Negotiating between these two dichotomous views on whether digital revolution creates utopia or dystopia, this article, by engaging with Badiou's theory on "event” and “organization”, hopes to move beyond this dichotomy by looking at a form of trans-border activism originally driven by suicides and protests of Foxconn workers who produce iPhones, iPads and many other i-gadgets for the world's consumers. As an attempt to explore a politics of online-offline resistance against digital capitalism, SACOM, based in Hong Kong (HK), is a leftist student group which works to support Chinese workers in campaigning against corporate power and generating trans-border networks through media exposure, international activism, and localized organizing (Litzinger, 2013). SACOM stands for Students and Scholars Against Corporate Misbehavior, which is a new form of labor campaign organization, founded in Hong Kong in June 2005. SACOM is originated from a students' movement devoted to improving the labor conditions of cleaners and security guards under the outsourcing policy on campus. The movement attained relative success and created an opportunity for students to engage in local and global labor issues. In brief, "SACOM aims at 
bringing concerned students, scholars, labor activists, and consumers together to monitor corporate behavior and to advocate for workers’ rights.” (SACOM, n.d.) Using Hong Kong as a trans-border public space which is nevertheless increasingly under the influence of the central government of China, SACOM endeavors to use the most effective means of monitoring by applying investigative journalism, media intervention and social campaigns in front of retail shops as well as collaborating closely with workers at the workplace level. With workers' empowerment as its core tenet, SACOM also teams up with labor NGOs to provide support to labor actions and in-factory training to workers in South China. "Through democratic elections, we support worker-based committees that can represent the voices of the majority of workers,” said SACOM organizers.

Combining online and offline activism, SACOM strives to extend the reach of their worker-consumer campaign to the worldwide audience by transgressing the Chinese state's dominance of capital and political control. The most intriguing question to us is could this proactive activism be possible and, if so, how could it act at the grid of China's transformation and incorporation into global capitalism? This article, in contrast to the common understanding that no activism is possible in China - while at the same time not being trapped between the utopia and dystopia of digital revolution - records and analyzes a trans-border initiative of student-worker activism that opens up not only a public space in China targeting Chinese issues but also a form of liminality that extends from local space to the global sphere. Drawn from SACOM's reports and worker interviews as well as participant observation and action research with concerned scholars, students and SACOM activists, we rely on a seven-year on-going ethnographic study and participation in the campaigns, and attempt to offer concrete analysis on SACOM's campaigns as a dynamic process of "event" and forms for organizing. This article also engages in debates on media, technology, 
autonomy, and social movement by providing a reflexive review of media theories, hoping to move beyond binary views and shed light on radical politics.

\section{Beyond Utopia and Dystopia: Media, Class and Politics}

Understanding Media, the classic written by Marshall McLuhan in the 1960s, is mostly likely the earliest work to imagine the "technological sublime.” McLuhan argues for existential extensions of the human being due to the revolution of media and technology. With striking "optimism of the intellectual will," he argues that the medium is the message, and our time is a revolutionary epoch that transforms not only the content and paradigm of communication, but communication itself. This new mode of communicative technology is a human extension that achieves the restructuring of human work and association and overcomes the technique of fragmentation that is the essence of machine technology (McLuhan, 1964, p. 8). Denouncing Marx's theory as an outdated product that belongs to the age of machine technology and can only explore human division, fragmentation, and class conflict, McLuhan fancied a new age of "electric light," a metaphor of the age that claimed media as medium, indifferent to the contents of the message, which acts as electric light that shapes and controls the scale and form of human association and action (1964, p. 9). Turning commodity fetishism into fetishized technology, McLuhan’s medium as message results in turning critics into euphoria and prophesied that the age of the medium, because of its power in emptying out "contents," is an age of human extension and social harmony (Ferguson, 1991; Jones, 1998).

In the light of McLuhan’s work, Manuel Castells, in his trilogy of the Information Age, is also a pioneer in highlighting that digital revolution could contribute to the openness of the world across different social classes in the age of the information society. Castells has claimed that we are now in the network society where the relationships of production, power, and experience are increasingly organized by different kinds of power-networking power, 
network power, networked power, and network-making power that altogether shape the domination and resistance of the society (Castells, 2009, pp. 42-47).

In his new book, Networks of outrage and hope (2015), in which he studied various social movements around the globe after the financial crisis of 2008, Castells was excited to claim that during the social movements, "there were first a few, who were joined by hundreds, then networked by thousands, then supported by millions with their voices and their internal quest for hope" that "cut across ideology and hype, to connect with the real concerns of real people in the real human experience that had been reclaimed” (2015, pp. 1-2).

How could this happen? Castells's answer is this: “It began on the Internet social networks, as these are spaces of autonomy, largely beyond the control of governments and corporations that had monopolized the channels of communication as the foundation of their power, throughout history” (2015, p. 2). Taking the Internet as "free public space,” Castells acclaimed an unprecedented autonomy for communicative subjects in which "by connecting to each other, and by envisioning projects from multiple sources of being, individuals formed networks, regardless of their personal views or organizational attachments. They came together” (2015, p. 2).

In a moment of intellectual inspiration from the new social movements after the financial crisis of 2008, Castells talks about power and counter-power in his various works (2009, 2011, 2015), where he asserts that there will be no deterministic control of the power structure by one group and argues that mass self-communication exists in the network society to check and balance the power of mass communication, which is controlled by political leaders and business elites. In our reading, Castells missed to undertake a serious analysis of the political economy of the networked society; class is basically evacuated from his analysis, even though he does take note of asymmetries in between different kinds of power. Castells was hence indifferent to the control of state and company power over cyberspace, and the 
arrests of civic protestors with the aid of informational technology, as well as the class conflicts and social resistance at the forefront of the struggle of media as both medium and message despite his tremendous contribution to our understanding of social movement in the network society.

In contrast to McLuhan and Castells, Christian Fuchs, Zhao Yuezhi and many others have provided critical studies on the political economy of information and communication, arguing that technology and media are actually embedded in the core of capitalist relation of production, which helps extend and reproduce capitalism into a stage of imperialism instead of generating a true "liberating effect" to challenge global capitalism. In this stance, Fuchs argues that "digital labor, as the newest frontier of capitalist innovation and exploitation, is central to the structures of contemporary imperialism," and "information technology has become a means of war” (Fuchs, 2016, p. 14).

In the Chinese context, Zhao Yuezhi's book Communication in China (2008) openly calls for a study that focuses on "the relations between the unequal distribution of control over systems of communications and wider patterns of inequality in the distribution of wealth and power, particularly between the mass media and the central axis of stratification-the class structure” (2008, p. 7). In fact, according to Zhao, media technology plays a central role in making and re-making the class inequalities in China, creating more alienation, dislocation, and exploitation. Far from the prophecy that the Internet could advocate free public space and create human extension and democracy, new development of information technology in China invites deeper and more tense class conflicts and struggles among transnational capital, private companies, state agents, and different classes of the society that deserve further indepth studies (see also Qiu, Castells, \& Cartier, 2009).

The beauty of having a class perspective on media and information technology is that it gears critics directly at the capital and state that serve as "invisible” hands to manipulate 
and monopolize new technology for the valorization of capital. The trap is that the structural analysis often offers a “control” story emptying out resistance politics or rendering it as lip service by repeatedly murmuring "where is control, where is resistance". While Greenfield (2017) has highlighted the concept of “infrapolitics” to illustrate everyday resistance to overcome the dominant mode of high technology in colonizing human life, the discussion provided by him is still lacking concrete operation with specific mechanisms in enforcing change (pp. 311-313).

Shedding light on Badiou's two concepts, “event” and "organization,” we strive to explore SACOM's dynamic process of campaigning and organizing in illuminating the radical politics. As Badiou said, “An event is signaled by the fact that an inexistent is going to attain genuine existence, an intense existence, relative to a world” (2012, p. 68). As a reopening of history, the event, Badiou argued, is heralded by three immanent processes in massive popular demonstrations: intensification, contraction, and localization (p. 63). Badiou also highlights the power of visibility in the symbolic realm that can expose the political action as an event. He argues that visibility as such is not reducible to visibility in the media, or what is called communication. In order for an event to achieve visibility, it has to be a universal address for the being of the inexistent to appear as existent - "something that initiates a transformation in the rules of visibility themselves.” (pp. 68-70). Then what is an organization? As Badiou said, an organization lies at the intersection between an idea and an event; is "an attempt to preserve the characteristics of the event (intensification, contraction, and localization), when the event as such no longer possesses its initial potency” (2012, p. 70). In this sense, SACOM, as an organization, is not a physical body per se, but an initiator, facilitator, and transformer of the political action that attempts to challenge digital capitalism targeting Apple and Foxconn. 


\section{Contextualizing SACOM in China's Global Capitalism}

SACOM was set up in the context that China has risen into a "world workshop" attracting massive flows of capital not only from Hong Kong, Taiwan, South Korea, and Japan but also the USA and Europe. As a giant “world workshop,” China has become the world's largest manufacturer of more than 200 products, including smart phones, garments, color TVs, DVD players, cameras, refrigerators, air-conditioners, motorcycles, microwave ovens, and bicycles (Pun, 2016, p. 6). The huge flow of transnational capital builds on a massive migration project calling on rural migrants to toil in the industrializing areas of urban China to serve the global capital of accumulation. The history of China as the world's factory is one of alienation, exploitation, and dislocation of more than 270 million rural migrant workers producing the world's most avant-garde products.

The triumph of a neoliberal world has signaled the opportunity for capital to invade the dreamland of socialist China in the form of large-scale investment and offshore production. At the end of the 1970s, global capital reached the stage of rapid expansion, destroying all potential barriers erected by non-capitalist or socialist nation-states for capital flows, technology transfer, expropriation of production materials and markets, and, last but not least, the use of abundant labor. The strategy of capital concentration or monopoly was achieved by penetrating into non-capitalist countries via a multiplication of global supply and production chains. The best examples are Apple and Foxconn, ranking $5^{\text {th }}$ and $31^{\text {st }}$ on the Global 500 List in 2015, respectively. About this circumstance, SACOM's core activist, Michael HO said,

Many students and scholars are deeply concerned about the dark side of corporate-led globalization. Corporations should commit to ensuring that working conditions in their supply chains are safe, workers are treated with respect and dignity, and manufacturing processes are environmentally responsible. (see also Juris, 2008) 
SACOM was organized by a group of committed student activists who studied in Hong Kong but are not restricted to Hong Kong locals. Having a composition of Hong Kong local students, mainland Chinese and Taiwanese students, SACOM's activists are highly aware of global capitalism and workers' exploitation. Armed by a belief in global worker justice, they have fiercely criticized most corporate codes of conduct and the audit system as window dressing strategies that are not effectively implemented. SACOM calls for reforms of the monitoring program that must include, as a central feature, the participation of the workers. The workers should be able to take part in the company's decision-making process about their rights and welfare. As the Chairperson of SACOM, Ken Yau said in summer of 2016, "We advocate for a transparent and democratic mechanism as follows:

First and foremost, corporations should disclose the names and locations of their supplier factories at different tiers;

Second, corporations should invite independent NGOs to provide participatory training with the workers on labor rights, corporate social responsibility, and consumer campaigns;

Third, the trained workers should be allowed to run factory-wide elections to select their own representatives for the workers' committee.

In short, this is an activism that attempts to extend the concerned subjects from workers in Mainland China to the students and young activists in Hong Kong with a call for global consumer support. It transgresses both physical and political barriers by extending labor actions and protests from China's industrialized areas to cross-border spaces in Hong Kong and the rest of the world where students and young activists can launch campaigns and protests in front of the retailers' stores to generate more counter-power pressurizing companies. Combining online and offline activism, SACOM also strives to achieve an 
extension of the worker-consumer campaign to reach a worldwide audience by transgressing the political control of the Chinese state.

\section{Attempts to Campaign against Appconn}

Jack Qiu, in his new book, Goodbye iSlave: A Manifesto for Digital Abolition (2016), has coined the term Appconn (Apple and Foxconn) to highlight the supremacy of economic superpowers in forging a slave labor regime predominantly in China. The rapid flight of global capital to China not only looks for cheap labor and low land prices but also for diligent, skilled and well-educated Chinese internal migrant workers and student interns from vocational schools who are willing to work in appalling conditions, who are suitable for justin-time production, and who are potential consumers of global products such as iPhones and iPads. Among the global retail (Apple), the Asian giant manufacturer (Foxconn) and the Chinese producers (Chinese migrant workers), Apple's strength is well illustrated by its ability to capture an extraordinary 58.5 percent of the value of the iPhone despite the fact that manufacture of the product was entirely outsourced. Particularly notable was that labor costs in China accounted for the smallest share, only 1.8 percent or nearly US\$10, of the US\$549 retail price of the iPhone (Karemer, Linden, \& Dedrick, 2011, p. 5). It is under this huge unfair re-distribution of wealth that we encountered a young woman worker who worked on the assembling line for Apple products and who attempted to end her life.

On March 17, 2010, a 17-year-old worker, Tian Yu, went to the window of her fourthstory dorm room at the Foxconn factory in Shenzhen and jumped. Tian Yu survived. Many more have followed Tian Yu's attempt to end her life even as global consumers race to consume new generation electronic products. Within twelve months, 18 young rural migrant workers attempted suicide at Foxconn facilities. As the world's largest electronics factory, Foxconn ate up a huge number of small factories in the same sector not only in China but also 
other parts of the world, spreading its facilities and offices over more than thirty countries. Unprecedented in history and incomparable over the globe, Foxconn has employed over 1 million staff and workers in its industrial empire, which is the major manufacturer of Apple and other brands. Under this monopoly capital, Chinese workers were induced to work in a global top 500 company, subjected to such work pressure that their desperation might lead to suicide on the one hand and also opens up daily and collective resistance on the other.

The suicides of Foxconn workers since 2010 alarmed the world. The suicide wave exposed the "invisible” laboring subjects in the world's workshop to the forefront of the spectacular. Echoing Badiou's theory of “event”, this was the moment of death: the missing of human lives that calls the "inexistence" to the existence-the origin and the life of activism that attempts to transgress all sorts of constraint under predatory transnational capitalism and the political control of the state. Saddened as suicides, the workers' actions politically and powerfully created the "event"- the visibility of the suffering, created by the technological sublime that could no longer subsume the working lives as "invisible” subjects.

Xu Lizhi, a Foxconn worker poet who ended his life on September 30, 2014, and left many extraordinary touching poems to the public, again forcefully screamed for the “inexistence" to come to life upon his death ${ }^{1}$ :

On My Deathbed

I want to take another look at the ocean,

Behold the vastness of tears from half a lifetime

I want to climb another mountain,

\footnotetext{
${ }^{1}$ After his death, Xu Lizhi's poems were widely circulated and reached out to an international audience. Many local artists and international labor groups helped translate and circulate his work.
} 
Try to call back the soul that I’ve lost

I want to touch the sky,

Feel that blueness so light

But unable to do any of these, I'm leaving this world.

Everyone who's heard of me

Shouldn’t be surprised at my leaving

Even less should you sigh or grieve

I was fine when I came, and fine when I left.

— Xu Lizhi, September 30, 2014 (Friends of the Nao Project, 2014)

Sparked by the spate of suicides and subsequent worker struggles, SACOM activists launched an experimental approach of cross-border activism involving researchers and activists from China, Hong Kong, and Taiwan, employing tactical actions to overcome physical and social barriers by anchoring both online and offline activities. By persistently launching the antidigital campaign, SACOM as an organization attempted to preserve the political event by actively contributing to what Badiou's highlighted as "intensification, contraction, and localization.”

\section{Suicide is Murder}

To achieving the potential of "intensification, contraction and localization", , when the $9^{\text {th }}$ Foxconn worker committed suicide on May 11, 2010, a number of intellectuals and students, including those from both Hong Kong and Mainland Chinese called a meeting to discuss possible actions. On May 18, 2010, a public statement was released. It read painfully (Sina Tech, 2010): 
From the moment they [the new generation of migrant workers] step beyond the doors of their houses, they never think of going back to farming like their parents. In this sense, they see no other option when they enter the city to work. The moment they see there is little possibility of building a home in the city through hard work, the very meaning of their work collapses. The path ahead is blocked, and the road to retreat is closed. Trapped in this situation, the new generation of migrant workers faces a serious crisis and, in effect, this magnifies psychological and emotional problems. Digging into this deeper level of our societal and structural conditions, we come closer to understanding the "no way back" mentality of these Foxconn employees.

In drafting the statement, the intellectuals and students paid particular attention to both the "medium" and the "content" of the letter. The only medium allowed was the Internet. The first consideration was whether the statement could be reported and quoted by Mainland Chinese media and whether it could navigate through the control and censorship of the electronic media by the Chinese government. This concern affected the wording and the presentation of the public statement, that is, the constitution of the meaning and the position of the speaking power. The other consideration was how to effectively react to Foxconn, whose public responses to workers' suicides were uniform: the workers who attempted suicides suffered from individual psychological problems such as depression, distress over heavy debts, or family and other personal problems. Foxconn hired Western and Chinese psychologists and psychiatrists to defend it in the wake of the plague of worker suicides at the company.

The intellectual statement was the first reaction to Foxconn, hoping to bring structural—rather than "personal" or psychological—factors to the forefront of the public 
agenda. They argued that the migrant working class that had become the core of China's new working class, the combination of exploitation in a global production system and an uncaring society, which denies rural migrants urban citizenship rights and does not allow migrant workers to organize themselves, is at the root of the worker suicides. Hundreds of millions of migrant workers like Foxconn employees are being thrown into a state of deep contradiction. They reject the regimented hardships their predecessors silently endured as cheap labor and second-class citizens. They rebel against their marginalized status and meaningless life. Hence, "throwing bodies through the dormitory building" is an act of frustration—and of defiance. In their defiant deaths, the workers call on the Chinese nation-and international society— to wake up before more lives are sacrificed. The statement argues:

In the absence of effective channels of expression and association, the suicide jumpers chose to sacrifice their lives as a means of accusation.... Was it suicide or murder? In this case, the evidence suggests that suicide was tantamount to murder. (Pun et al., 2014)

Powerfully re-signifying workers' suicides as murder, this first public statement was then widely circulated on the Internet and repeatedly extended through blogs and microblogs to the public audience in Mainland China. SACOM and labor NGOs also created blogs dedicated to the Foxconn worker victims and their families, with the theme song "Grief” spreading quickly throughout the web (Fu \& Chau, 2014). By manipulating the relatively free public space in Hong Kong, SACOM advocated June 8, 2010, the date of Foxconn International Holdings' shareholder meeting, as the Global Day of Remembrance for Foxconn Victims. Student protestors from SACOM, Hong Kong labor unions, and rights groups demonstrated outside an Apple store to hold Apple and Foxconn accountable to workers' rights, supporting the intellectuals and student activism in Mainland China. On top of protests on the ground, 
SACOM issued its first public letter to Apple CEO Steve Jobs (SACOM, 2010) condemning Apple for squeezing its suppliers worldwide with too little concern for the effects on the workers who produce their products.

SACOM wrote, "Workers have a right to a fair, living wage” (see also Sun, 2012). It further condemned the ineffectiveness of the Chinese government and trade unions to enforce labor law and protection of the migrant workers and hence urged Apple and other brands to support genuine reform of Foxconn's unions. SACOM proposed, “Through elections and genuine participation, workers will find their voice, ensure respect for their rights and dignity and stop this trend of Foxconn employee's choosing to end their lives in the prime of their youth.” Sent to Steve Jobs' office, this public letter was circulated widely and intensively through Facebook, Twitter, and various social media channels. Through protests in front of Apple stores and the circulation of public statement through social media, an appeal was sent to NGOs and labor activists worldwide who were ready to support the workers at Foxconn. Online-offline cross-border activism was attempted for the first time in Mainland China and Hong Kong and extended to other parts of the world.

\section{Cross-border Linkages and International Support Actions}

Across the straits, more than 300 Taiwanese issued another open statement, and on June 13, 2010 they held a press conference to condemn Foxconn management and its brutality toward Mainland workers. Benefiting from a more open society, Taiwan scholars issued a set of demands to Foxconn, Apple, the Chinese government, and consumers (Lin \& Yang, 2010):

To Foxconn, we ask for an end to military discipline in the factory as well as the dormitory, the improvement of working and living conditions of the workers, and the establishment of a humane production-line process.... 
We urge the Chinese government to raise the statutory minimum wage to a level that meets the basic needs of urban living, to abolish household registration system under which people are segregated into "the local" and the "the outsiders."

Third, multinational companies especially Apple should take responsibility for the tragedies occurred at Foxconn. Poor conditions, low wage levels and inhumane mode of labor discipline of Taiwanese companies have much to do with the price competition of global brands such as Apple, HP and Dell.

Finally, we urge consumers to boycott iPhone 4G until the working conditions of its manufacturing factories have genuinely been improved.

On the basis of these two open statements linking scholars and students from Mainland China, Hong Kong, and Taiwan, a large-scale collective investigation of Foxconn was set up in the summer of 2010. The tragic suicides emblematic of myriad labor problems at the workplaces that produce the world's most sought after products, as well as the strength of a survivor like Tian $\mathrm{Yu}$, prompted the students and the young activists across the border to dip into the Chinese and global context of international electronic capital.

\section{The Political Context of the Independence Investigation Project}

At the peak of the suicide cluster in the spring of 2010, rather than analyzing and taking actions to overcome the root causes of suicides, Chinese officials moved to ban "negative" reporting about Foxconn. The Chinese government's banning of news about the suicides created intense anxiety, if not anger, among Chinese teachers and students. The need to conduct in-depth field research on Foxconn workers' conditions was pressing. Despite the risks, teachers and students launched a large-scale investigation in June of 2010. 
Since mid-July 2010, faculty and students from 20 universities in Mainland China, Taiwan, and Hong Kong have joined to form a University Research Group on Foxconn. Together with SACOM, over sixty researchers joined forces to conduct independent investigations of Foxconn's labor practices and production system. Forty of the scholars and students arrived at Shenzhen Longhua from different parts of the country, Hong Kong, and Taiwan and received basic training on the company profile, interview skills, and a guideline to research ethics and personal safety. The research group, worried about the political sensitivity and the risks, divided into smaller teams, settling at different hostels, before carrying out interviews and surveys in the industrial communities. The research was mainly done in the industrial communities as Foxconn workers, easily identified by their uniforms and staff cards, came out for lunch and dinner, and during their rest days. During meal times, thousands of workers poured out to the street food stalls. Researchers also targeted workers changing shifts from day to night, or night to day, the gap hours between shifts providing more time to conduct in-depth interviews. They also visited nearby clinics and hospitals to visit injured workers, who told us about how they were injured and about their grievances. For two consecutive weeks, every day, the study started around 11 a.m. and lasted until 10 p.m. Group meetings and discussion on the findings of the investigation began at 10:30 p.m. With heated debates, these meetings lasted until midnight or early morning (Pun et al., 2014).

Surprisingly, the research group encountered no direct intervention from Foxconn or the local state throughout the summer. To supplement survey and in-depth interviews, 14 Mainland Chinese students entered Foxconn to work as frontline workers to collect first-hand information about conditions in the plants and workers' lives for one month. Altogether, in the first phase, between June and December 2010, they interviewed and surveyed workers and managers at major Foxconn factory complexes in nine coastal and inland cities where the company's factories were then concentrated. This resulted in a Cross Border University 
Research Report on Foxconn, released in a press conference at Peking University on October 9-10, 2010. A copy of the report was sent to Foxconn, Apple, the State Council of the People's Republic of China, and the All-China Federation of Trade Unions. Though there was no direct response from the related parties, the report, when posted on a blog by the Mainland students, was read by over 350,000 people in a single night, and surprisingly the web police did not remove it. On the second day, the major findings of the study were reported widely by the mainstream media not only in Mainland China, Hong Kong, and Taiwan but also the rest of the world (see also Yang, 2009).

\section{Gazing at Apple and Foxconn: Trans-border Practice and the Global Campaign}

Under such pressure, and together with Mike Daisey’s drama, “the Agony and the Ecstasy of Steve Jobs" that appealed to the American audience as well as the pressure generated by a Beijing-based environmental group which released report on Apple's ecological risk (see Litzinger 2013), Apple released its Supplier Responsibility Progress Report in February 2011 to show the remedial measures taken by Foxconn, its largest supplier, in the aftermath of the suicides. However, none of the "remedial measures" addressed such core issues as speed-up, illegal levels of compulsory overtime work, dangerous conditions in Foxconn factories, the humiliation of workers, and illegal practices associated with the use of student interns as workers.

Foxconn, on the other hand, became notorious in the world's media. From June 1, 2010, facing the dual pressures of the international criticism following the suicides and the tight labor market in Shenzhen, Foxconn raised the basic wage of its production operators in Shenzhen to 1,200 Yuan (US\$190) a month, that is, 9 percent above the local minimum statutory wage. This still meant that, if a Foxconn worker wished to buy Apple's lowestpriced iPad at US\$499, it would cost them about a total of two months' income (including 
overtime premiums). In February 2012, Foxconn announced a wage increase to 1,800 Yuan a month (US\$285) for entry-level workers in Shenzhen, but at the same time Foxconn started to relocate workers to Zhengzhou and Chengdu where they provided a lower minimum wage and recruited student interns as cheap labor.

In order to check on the fulfillment of the promises made by Apple and Foxconn and generate continuous pressure on them, the University Research Group and SACOM conducted second-phase research from March to December 2011. In addition to revisits to Foxconn factory complexes in Shenzhen and Kunshan, they investigated conditions in three new Foxconn complexes in the central and southwestern provinces into which it was expanding in the search for increasingly scarce labor.

In the third phase, from January 2012 to the present, SACOM has been working closely with worker activists and students from Mainland China and students from Hong Kong and Taiwan who have studied Foxconn plants in Shenzhen, Chengdu (exclusive production of iPads), and Zhengzhou (exclusive production of iPhones) in depth. In addition to the 3000-person surveys conducted in Shenzhen, Zhengzhou, and Chengdu, SACOM and the Research Group have documented over 500 workers’ narratives to present the working and everyday lives of the young Foxconn employees. The University Research Group on Foxconn released three more reports upon the completion of each phase of the investigation. The second and third reports squarely targeted the use of student interns as a new, cheap, and expendable form of labor in Foxconn in the process of rapid expansion and called for the legally mandated protection of student laborers. The final report in 2015 focused on the issue of trade union elections and workers' participation at the Foxconn workplaces in Shenzhen, Chengdu, and Zhengzhou.

Given the work and study pressures that most students face during the semester, a trans-border campaign that gradually evolved into a global one could hardly have been 
achieved without SACOM. In order to pressure Apple and Foxconn, besides organizing the Global Day of Remembrance for Victims of Foxconn in June 2010, SACOM urged GoodElectronics and makeITfair to join the IT campaign and mobilize their partners in the network to protest against Foxconn. This further encouraged more activism and international solidarity worldwide. On the west coast of the US, the Chinese Progressive Association held a candlelight vigil for the Foxconn victims and their families in San Francisco. The memorial ceremony featured solemn teenagers holding signs with the names of Foxconn workers who took their own lives. On June 14, United Students Against Sweatshops (USAS), working through a nationwide network of over 150 American college and high school chapters, sent an open letter urging Apple CEO Steve Jobs to "address the problems in Shenzhen by ensuring payment of living wages, legal working hours, and democratic union elections in Foxconn supplier factories.” (USAS, 2010). Two years later, in April 2012, Rutgers USAS members staged a sit-in at the university president's office to call on the university to immediately cut ties with the Fair Labor Association (FLA), which “can't and won’t hold corporations accountable when Nike and Apple control the FLA’s Board of Directors”(Ibid., 2012).

It looks as if SACOM never gave up its campaigns and activism even when the media was cooled down in the subsequent years. In September 2017, SACOM launched "NO More iSlave! - Call for Global Action Day to End Apple’s iSlavery", when Apple announced its releasing day of iPhone $\mathrm{X}$ and celebrated the $10^{\text {th }}$ anniversary of iPhone products. Instead of producing lengthy reports, SACOM produced three short videos and animations on use of student interns, wage and fake union election, more skillfully using new technology to protest Apple’s supply chain. In SACOM's iSlave at 10” campaign, three-major demands are sent to Apple:

1. Full trade union right for all workers

2. Double the basic wage for workers' live diginity 


\section{Stop labor flexibilization}

In term of organizing, SACOM uses multiple online-offline strategies and actions for intensifying mobilization:

1) Workers' Roar: Protesting in front of the Apple flagship store in your region. Telling Apple the demands of workers by yelling slogans or any other ways

2) Photo Campaign: Holding photo boards and take pictures in front of Apple store while consumers are lining up. Aiming to tell media and the public the reality of Apple

3) Online Campaign: Sharing SACOM’s documentaries and animations on Facebook, Twitter and other online platform with the tags \#nomoreislave and \#islaveat10 to spread the truth of Apple

\section{Concluding Remarks}

This article documents the formation of a cross-border online-offline activism and illustrates how the organization and mobilization of SACOM, sociological research, investigative journalism, student activism, and a media campaign could fuel localized campaigns that gradually developed into a global campaign. This experience confirms that online and offline activism should never be separated. We attempt to bring about a new understanding of the transformative event, the relationship between global production and worker resistance in China, about potential movements, and about the goals of social change. We also highlight how, by combining the strengths of workers, students, researchers, and transnational movement activists, social and economic injustice could be creatively challenged.

Obviously constrained by the dominant structure of the political economy of capital, state, and informational economy, SACOM, in Alan Badiou's sense, is a transgression of 
traditional party organization or trade unionism that instead draws on counter-power from workers, students, teachers, young activists and consumers and attempts to build an organizing capacity with networking power that transgresses physical barriers, political control, and capital dominance. Combining online and offline activism, SACOM is able to contribute to the intensification of the event, spreading the spectacle of the suicides, alarming the world about the working conditions of the producers of iPhone and iPad gadgets and connecting the deaths to the ethical consumption of the world's consumers. By persistently conducting investigation reports and releasing numerous public statements, SACOM enables the process of contraction by pinpointing that "suicide is tantamount to murder" of the global production system, within which the state is an agent of capital and the digital economy is part of it, a metonymy of the overall situation. Over the years, with less mass media reporting, the momentum of anti-Apple and Foxconn campaigns has gradually faded, and the "event as such no longer possesses its initial potency.” Yet with SACOM as a persistent acting force, the "inexistence" of the factory workers, the suicides, and the social resistance are at least able to "appear as existent," asserting in the world the visibility of universal justice against digital capitalism.

While not all the SACOM campaigns were prescribed with an "Idea of Communism" (Lee \& Žižek, 2016), the students and young activists nevertheless are armed with a firm vision to challenge the monopoly of capital, the terror of digital capital power, and an alternative to new forms of post-capitalistic society. In brief, SACOM contributes to the transformation of the "event" in the following ways:

1. An extension of political subjects from workers to students and young activists and then to consumers in challenging the world's digital power, Apple, and the oligarchic industrial power, Foxconn, even though the contribution of consumers is debatable and much less than students and young activists. 
2. An extension of political space from localized industrial areas in China, through Hong Kong, to Taiwan, the US, and Europe in targeting Apple and Foxconn as a monopoly of capital and exposing the evils of global capitalism.

3. An intensification of resisting power through a rapid constellation of social space and cyberspace in launching campaigns online and offline against Apple and Foxconn on the exploitation of the workers in general, and the use of student labor in particular.

4. A visibility of the "inexistence" to the forefront of the spectacular gazing at Apple and Foxconn and a strong calling to end the unsustainable global production and consumption system and the capitalistic mode of life.

Far from saying that SACOM is a successful model of future activism, we find that it shares many similar features of other significant global campaigns such as campaigns against Monsanto, PepsiCo and Palm Oil production, etc. Like all these global campaigns, SACOM, as an organization, is situated at the grid of the extended reproduction of global capitalism and the transformation of state socialism, is confronted with enormous challenges and limitations. For example, the interests of producers and consumers are always structurally contradictory to each other in the process of production, consumption, and distribution of values, and hence appeals to Western consumers to support the workers' campaigns are ineffective. Needless to say, we do not observe the transcendence of social classes by digital technology used in the movement as prophesied by Marshall McLuhan and Manuel Castells.

Second, local workers in Foxconn plants and teachers and students in Greater China can work closely in the stages of investigative reports and even running press conferences together, but once the campaigns go international, workers usually lack material support and language capacity to join the movement overseas. Last but not least, the formidable challenge to SACOM is the control and pressure coming directly from the state, which through 
censorship, political detainment, and threat to arrest limits the scope of mobilization and organizing. Many workers and students are not able to disclose their identity in the course of activism.

In the course of cross-border activism, SACOM is nevertheless able to document labor strikes, protests, and riots in various Foxconn facilities and dormitories. These collective labor actions are now challenging the Foxconn and Apple managements. These labor struggles, while thus far dispersed and spontaneous, are spreading across China. With new factory operations in West and Central China, a substantial portion of rural workers are being recruited from within their home province and even their hometown or prefecture. We anticipate that the form of labor resistance for rural migrants will change as they work closer to their native place and have the opportunity to draw on local social networks. With support from SACOM, traditional collective actions will be hooked up with connective actions, and there is potential to create a radical politics for Chinese worker activism to elevate to a higher regional or global level (Fenton, 2016). Neither "pessimism of the intellect” nor "optimism of the will” offers insight into possibilities of this kind of activism that shed light on our future activism.

\section{References:}

Apple (2011). Apple Supplier Responsibility: 2011 Progress Report p.19. Retrieved from Apple.com: http://apple.co/2dbcCnh

Badiou, A. (2012). The rebirth of history: Times of riots and uprisings. (G. Elliott, Trans.). London and New York: Verso Books.

Bennett, W. L., \& Segerberg, A. (2012). The logic of connective action: Digital media and the personalization of contentious politics. Information, Communication \& Society, 15(5), 739-768. 
Berman, M. (1983). All that is solid melts into air: The experience of modernity. London and New York: Verso Books.

Lee, A. \& Žižek, S. (Eds). (2016). The Idea of Communism (Vols. 3). London and New York: Verso.

Castells, M. (2008). The new public sphere: Global civil society, communication networks, and global governance. The ANNALS of the American Academy of Political and Social Science, 616(1), 78-93.

Castells, Manuel. (2009). Communication Power. Oxford, New York: Oxford University Press.

Castells, M. (2015). Networks of outrage and hope: Social movements in the Internet age. Malden, MA: Polity Press.

Fenton, N. (2016). Left out? Digital media, radical politics and social change. Information, Communication \& Society, 19(3), 346-361.

Ferguson, M. (1991). Marshall McLuhan Revisited: 1960s Zeitgeist Victim or Pioneer Postmodernist? Media, Culture and Society 13(1), 71-90.

Friends of the Nao Project. (October 29, 2014). The Poetry and Brief Life of a Foxconn Worker: Xu Lizhi (1990-2014). Retrieved November 13, 2016 from https://libcom.org/blog/xulizhi-foxconn-suicide-poetry

Fu, K. W., \& Chau, M. (2014). Use of microblogs in grassroots movements in China: exploring the role of online networking in agenda setting. Journal of Information Technology \& Politics, 11(3), 309-328.

Fuchs, C. (2009). Some Reflections on Manuel Castells' Book “Communication Power”.tripleC: Communication, Capitalism \& Critique. Open Access Journal for a Global Sustainable Information Society, 7(1), 94-108.

Fuchs, C. (2016). Digital Labor and Imperialism. Monthly Review, 67(8), 14. 
Jones, P. (1998). The Technology Is not the Cultural Form? Raymond Williams's Sociological Critique of Marshall McLuhan. Canadian Journal of Communication 23(4), 423-454.

Juris, J. S. (2008). Networking futures: The movements against corporate globalization.

Durham, N.C.: Duke University Press.

Kraemer, K., Linden, G., \& Dedrick, J. (2011). Capturing value in Global Networks: Apple’s iPad and iPhone. Retrieved from: http://bit.ly/2dY9Xfj

Li Li. (June 12, 2010). Alleviating Workplace Stress. Beijing Review. Retrieved November 13, 2016 from http://www.bjreview.com.cn/nation/txt/2010-06/12/content_279009.htm

Lin T. H. \& Yang, Y.R. (2010). The Foxconn employees and to call to the attention.

Retrieved November 13, 2016 from https://sites.google.com/site/laborgogo2010eng/

McLuhan, M. (1964). Understanding media: the extensions of man. London and New York: Routledge.

Pun, N. (2016). Migrant labor in Post-Socialist China. New York and London: Polity Press. Pun, N. et al. (2014). Worker-Intellectual Unity: Trans-border Sociological Intervention in Foxconn. Current Sociology, 62(2), 209-223.

Qiu, J. L., Castells, M., \& Cartier, C. (2009). Working-class network society: Communication technology and the information have-less in urban China. Cambridge, Massachusetts; London: MIT Press.

Qiu, J. L. (2016). Goodbye iSlave: A manifesto for digital abolition. Urbana: University of Illinois Press.

Sina Tech. (May 19, 2010). Nine Sociologists published an open letter: Put an end to Foxconn tragedy [Jiu ming she hui xue zhe fa gong kai xin: du jue fu shi kang bei ju]. Retrieved November 13, 2016 from http://bit.ly/2etuMRW Students and Scholars Against Corporate Misbehavior. http://sacom.hk/about-us 
Students and Scholars Against Corporate Misbehavior (June 8, 2010). Open letter to Apple CEO Steve Jobs. Retrieved November 13, 2016 from http://sacom.hk/open-letter-toapple-ceo-steve-jobs/

Sun, W. (2012). Desperately seeking my wages: justice, media logic, and the politics of voice in urban China. Media, Culture \& Society, 34(7), 864-879.

Tong, J. (2011). Investigative journalism in China: Journalism, power, and society. London: Continuum.

United Students Against Sweatshops. (June 14, 2010). Open Letter to Apple CEO Steve Jobs. Retreived November 13, 2016 from http://usas.org/files/2010/06/20100617_mahoney_to_apple_061410.pdf

United Students Against Sweatshops. (April 27, 2012). Rutgers Students Occupy President's Office. Retrieved November 13, 2016 from http://usas.org/2012/04/27/rutgers-sitin/

Zhao, Y. (2008). Communication in China: Political economy, power, and conflict. Lanham, Md.: Rowman \& Littlefield Publishers.

Litzinger, R. (2013). The Labour Question in China : Apple and Beyond. South Atlantic Quarterly. 112(1), 172-178.

Yang, G. B.. (2009). The power of the Internet in China: Citizen activism online. New York: Columbia University Press. 